of the opinion that the smaller firms which the research associations are particularly designed to help are often "poor mombers". There was general agreement that the best place to do industrial research is in industry and that, ideally, government and co-operative efforts should cover those fields not adapted to research by individual firms.

\section{AFRICAN HONEY-GUIDES}

$\mathrm{A}$

MONG the strangest forms of animal behaviour $A$ is that of the honey-guides, African birds distantly related to the American woodpeckers, which 'guide' men, baboons and ratels (honeybadgers) to the nests of wild honeybees-supposedly so that these nests can be broken open.

A study of the behaviour is described by Dr. Herbert Friedmann, U.S. National Museum curator of birds, in a bulletin issued by the Smithsonian Institution, Washington. Dr. Friedmann has observed at least twenty-three instances of the habit and has collected other well-authenticated data from African associates.

Dr. Friedmann describes the behaviour as follows : "When the bird is ready to begin guiding, it either comes to a person and starts a repetitive series of churring notes or it stays where it begins calling these notes and waits for the human to approach it more closely. If the bird comes to the person to start leading him, it flies within 15 or 20 feet from him, calling constantly and fanning its tail. If it waits for the potential follower to approach it for the trip to begin, it usually perches on a fairly conspicuous branch, churring rapidly, fanning its tail, and slightly arching and ruffling its wings so that at times its yellow shoulder bands are visible.

"As the person comes to within 15 to 50 feet from it, the bird flios off with an initial conspicuous downward dip, and then goes off to another tree, not necessarily in sight of the follower ; it is more often out of sight than not. It waits there, churring loudly until the follower again nears it, when the action is repeated. This goes on until the vicinity of the bees' nest is reached. Here the bird suddenly ceases calling and perches quietly in a tree nearby. It waits there for the follower to open the hive and usually remains until the person has departed with a collection of honeycomb, when it comes down to the plundered bees' nest and begins to foed on the bits of comb left strewn about. The time during which the bird may wait quiotly may vary from a few minutes to well over an hour and a half."

African natives regard the bird as an almost infallible guide to honey. They try to attract it by grunting like a ratel or chopping on trees to imitate the sound of opening a nest. Dr. Friedmann suggests that the habit is purely on an instinctive level and is not a deliberately associative act. It presumably originated before the advent of human beings, perhaps starting with the ratel, that still co-operates with the bird, and whose place in the association the African natives have deliberately tried to take. The honey-guide does not seem interested in the honey per se, or in the grubs of bees found in the nests. It has an insatiable appetite for the beeswax, which it will take wherever it can be found. With various collaborators, Dr. Friedmann is now carrying out an intensive study of the mechanism of wax digestion.

\section{THE NATIONAL TRUST ANNUAL REPORT}

$\mathrm{T}$

HE sixtieth annual report of the National Trust, prosented to the annual general meeting in Manchester on November 24-the first to be held out of London-records that there are now a hundred and twenty historic houses in the care of the Trust, which owns more than 220,000 acres and has a membership of more than fifty thousand, compared with a membership of seven thousand in 1945 when the Trust had sixty-three houses and owned 107,000 acres, and in 1914 a membership of $725,5,500$ acres and a handful of historic houses. The National Trust Act of 1937 specifically extended the purposes of the Trust to include the preservation of furniture, pictures and other works of art, and since that date the Trust has become responsible for many important collections associated with the country houses under its care. Its responsibility for works of art is likely to increase since the Finance Act of 1953 empowered the Treasury to accept, in payment of death duties, chattels associated with historic houses in the ownership of the 'Trust. The annual roport gives some account of the work of the Trust in this field, and at the annual general meeting Prof. A. B. Blunt, surveyor of the Queen's pictures and director of the Courtauld Institute, who has for some years been the 'Trust's honorary adviser on paintings, also described some of the maintenance problems that arise.

The report emphasizes that the Trust does not regard its primary duty, in respoct of its farmlands and the preservation of the unspoilt landscape committed to its care, as in any way conflicting with the interests of good farming, and the policy of modernizing the farms continues steadily. Deeds of dedication have now been completed with the Forestry Commission in respect of some 4,699 acres of the 'Trust's 30,000 acres of woodland, including 1,095 acres at Clumber, where, with the release by the Army of 850 acres, the whole property is now open to the public. For the first time since 1947, the accounts show a small surplus (£979) on the maintenance and administration of the Trust's general properties; but, although the income from annual

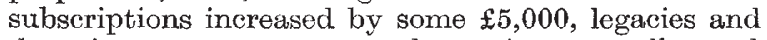
donations are at present decreasing annually, and a large increase in membership is essential if the Trust is to do no more than watch over a fraction of the property requiring its care.

The Trust aims at a membership of seventy thousand before the end of 1956, and, in stressing the urgent need for such an increase, Lord Chorley warned the annual general meeting of the great danger of complacency. The danger to the great country houses is more acute than ever, and at present the Trust can only accept such houses if an ondowment for all time is offered with the house. Lord Derby, who also addressed the meeting, stressed the voluntary standing of the Trust and made it clear that the Trust depends on private support and not on national contributions. He said that he was impressed by the small amount of litter left by the public when they visit Knowsley, in contrast with the amount left at many of the 'Trust's properties where admission is free. Reference was also made at the annual meeting to the launching of a scheme of corporate membership, by which it is hoped to enrol organizations such as industrial firms. 